\title{
Front Matter: Volume 7065
}

, "Front Matter: Volume 7065," Proc. SPIE 7065, Reflection, Scattering, and Diffraction from Surfaces, 706501 (23 September 2008); doi:

$10.1117 / 12.806360$

SPIE Event: Optical Engineering + Applications, 2008, San Diego, California, United SPIE. States 


\title{
PROCEEDINGS OF SPIE
}

\section{Reflection, Scattering, and Diffraction from Surfaces}

\author{
Zu-Han Gu \\ Leonard M. Hanssen \\ Editors
}

11-12 August 2008

San Diego, California, USA

Sponsored and Published by

SPIE

Volume 7065 
The papers included in this volume were part of the technical conference cited on the cover and title page. Papers were selected and subject to review by the editors and conference program committee. Some conference presentations may not be available for publication. The papers published in these proceedings reflect the work and thoughts of the authors and are published herein as submitted. The publisher is not responsible for the validity of the information or for any outcomes resulting from reliance thereon.

Please use the following format to cite material from this book:

Author(s), "Title of Paper," in Reflection, Scattering, and Diffraction from Surfaces, edited by Zu-Han Gu, Leonard M. Hanssen, Proceedings of SPIE Vol. 7065 (SPIE, Bellingham, WA, 2008) Article CID Number.

ISSN 0277-786X

ISBN 9780819472854

Published by

SPIE

P.O. Box 10, Bellingham, Washington 98227-0010 USA

Telephone +1 3606763290 (Pacific Time) · Fax +1 3606471445

SPIE.org

Copyright (C) 2008, Society of Photo-Optical Instrumentation Engineers

Copying of material in this book for internal or personal use, or for the internal or personal use of specific clients, beyond the fair use provisions granted by the U.S. Copyright Law is authorized by SPIE subject to payment of copying fees. The Transactional Reporting Service base fee for this volume is $\$ 18.00$ per article (or portion thereof), which should be paid directly to the Copyright Clearance Center (CCC), 222 Rosewood Drive, Danvers, MA 01923. Payment may also be made electronically through CCC Online at copyright.com. Other copying for republication, resale, advertising or promotion, or any form of systematic or multiple reproduction of any material in this book is prohibited except with permission in writing from the publisher. The CCC fee code is $0277-786 \times / 08 / \$ 18.00$.

Printed in the United States of America.

Publication of record for individual papers is online in the SPIE Digital Library.

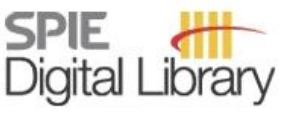

SPIEDigitalLibrary.org

Paper Numbering: Proceedings of SPIE follow an e-First publication model, with papers published first online and then in print and on CD-ROM. Papers are published as they are submitted and meet publication criteria. A unique, consistent, permanent citation identifier (CID) number is assigned to each article at the time of the first publication. Utilization of CIDs allows articles to be fully citable as soon they are published online, and connects the same identifier to all online, print, and electronic versions of the publication. SPIE uses a six-digit CID article numbering system in which:

- The first four digits correspond to the SPIE volume number.

- The last two digits indicate publication order within the volume using a Base 36 numbering system employing both numerals and letters. These two-number sets start with 00, 01, 02, 03, 04, 05 , $06,07,08,09,0 A, O B \ldots$. OZ, followed by 10-1Z, 20-2Z, etc.

The CID number appears on each page of the manuscript. The complete citation is used on the first page, and an abbreviated version on subsequent pages. Numbers in the index correspond to the last two digits of the six-digit CID number. 


\section{Contents}

vii Conference Committee

\section{SESSION 1 THEORY AND ANALYSIS I}

706505 Reduced Rayleigh equations in the scattering of s-polarized light from and its transmission through a film with two one-dimensional rough surfaces [7065-47]

T. A. Leskova, A. A. Maradudin, Univ. of California, Irvine (United States)

706506 The design of random surfaces that produce nonstandard refraction of light [7065-04]

T. A. Leskova, A. A. Maradudin, Univ. of California, Irvine (United States); I. Simonsen,

Norwegian Univ. of Science and Technology (Norway)

\section{SESSION 2 INSTRUMENTS AND APPLICATIONS I}

706507 Utilization of the Scheimpflug-principle in scatterometer design [7065-05]

C. Hahlweg, H. Rothe, Helmut Schmidt Univ., Univ. of the Federal Armed Forces Hamburg (Germany)

706508 Variable-angle directional emissometer for moderate-temperature emissivity measurements [7065-06]

A. R. Ellis, Sandia National Labs. (United States); H. M. Graham, Lockheed Martin Aeronautics Co. (United States); M. B. Sinclair, J. C. Verley, Sandia National Labs. (United States)

706509 Improved hyperspectral imagery using diffuse illumination or a polarizer [7065-07]

D. Wellems, D. Bowers, Applied Technology Associates (United States)

\section{SESSION 3 THEORY AND ANALYSIS II}

7065 OB Modeling scatter in composite media (Invited Paper) [7065-09]

E. C. Fest, Raytheon Missile Systems (United States)

7065 OD Goos-Haenchen effect applied for the design of Collett-Wolf beams [7065-11] Z.-H. Gu, Surface Optics Corp. (United States); A. Wang, Surface Optics Corp. (United States) and Univ. of Science and Technology of China (China)

7065 OE Unification of geometric and diffractive scattering from random rough surfaces [7065-12] B. Aschenbach, Max-Planck-Institut für extraterrestrische Physik (Germany) 
7065 OF An infrared laser-based reflectometer for low reflectance measurements of samples and cavity structures [7065-13]

J. Zeng, L. Hanssen, National Institute of Standards and Technology (United States)

7065 OG Controlling and measuring the polarization state of light using compound gratings and other plasmonic/photonic crystal structures and applications to polarimetric sensors [7065-14]

D. Crouse, City College of New York (United States)

$7065 \mathrm{OH} \quad$ Rough surface scatterometry of bodies with rotational symmetry [7065-15]

C. Hahlweg, H. Rothe, Helmut Schmidt Univ., Univ. of the Federal Armed Forces Hamburg (Germany)

70650 ol A fast and accurate image-based measuring system for isotropic reflection materials [7065-16]

D. B. Kim, K. Y. Kim, K. S. Park, M. K. Seo, K. H. Lee, Gwangju Institute of Science and Technology (South Korea)

\section{SESSION 5 OPTICAL DIAGNOSTICS I}

7065 OL Control of tiny dew droplet deposited on a copper plate by scattered laser light [7065-19] S. Matsumoto, Univ. of Industrial Technology (Japan)

$70650 \mathrm{M}$ An optical accessory for absolute reflection and transmission measurements in the wavelength region from $0.24 \mu \mathrm{m}$ to $25 \mu \mathrm{m}$ [7065-20]

E. Kawate, National Institute of Advanced Industrial Science and Technology (Japan)

\section{SESSION 6 TISSUE OPTICS AND DRUG ANALYSIS}

706500 Scattering depolarization by a bio-medium with anisotropic bio-molecules [7065-22]

T.-W. Nee, S.-M. Foeng Nee, National Yang Ming Univ. (Taiwan)

7065 OP Polarization of dipole scattering by isotropic medium [7065-23]

S.-M. Foeng Nee, T.-W. Nee, National Yang Ming Univ. (Taiwan)

$70650 Q \quad$ Spatially resolved spectral imaging of pharmaceutical powders [7065-24]

G. E. Carver, S. Rangwala, Princeton Lightwave (United States)

\section{SESSION 7 OPTICAL DIAGNOSTICS II}

7065 OR Light-scattering properties of a woven shade-screen material used for daylighting and solar heat-gain control [7065-25]

J. C. Jonsson, E. S. Lee, M. Rubin, Lawrence Berkeley National Lab. (United States) 
7065 OT Analysis of the uniqueness of an inverse grating characterization method [7065-27] B. Trauter, Carl Zeiss SMT (Germany) and Univ. of Heidelberg (Germany); J. Hetzler, Carl Zeiss SMT (Germany); K.-H. Brenner, Univ. of Heidelberg (Germany)

7065 OU NIR reflectance method to determine moisture content in food products [7065-28] C. V. K. Kandala, USDA Agricultural Research Service (United States); G. Konda Naganathan, J. Subbiah, Univ. of Nebraska (United States)

\section{SESSION 8 THEORY AND ANALYSIS III}

7065 OV Representative layer theory: describing absorption by particulate samples (Invited Paper) [7065-29]

K. D. Dahm, D. J. Dahm, Rowan Univ. (United States)

7065 oW A procedural model of reflection from random rough surfaces [7065-30]

L. M. Hanssen, A. V. Prokhorov, National Institute of Standards and Technology (United States)

7065 OX Modeling of femtosecond pulse propagation through dense scattering media [7065-31] N. Rivière, M. Barthélèmy, T. Dartigalongue, L. Hespel, Onera (France)

\section{SESSION 9 OPTICAL DIAGNOSTICS III}

7065 OY A comparison of optical properties between high density and low density sintered PTFE [7065-33]

B. K. Tsai, D. W. Allen, L. M. Hanssen, B. Wilthan, J. Zeng, National Institute of Standards and Technology (United States)

$70650 Z$ Pump probe experiment for high scattering media diagnostics [7065-34] M. Barthélemy, N. Rivière, L. Hespel, T. Dartigalongue, Onera (France)

POSTER SESSION

706512 Steel hardness and their optical properties [7065-37]

J. G. Suárez-Romero, Instituto Tecnológico de Querétaro (Mexico); E. Tepichin-Rodríguez, Instituto Nacional de Astrofísica Óptica y Electrónica (Mexico); E. Secundino-Palma, Instituto Tecnológico de Querétaro (Mexico); E. Hernandez-Gomez, Centro de Investigación en Ciencia Aplicada y Tecnologica Avanzada (Mexico)

706515 Measurement method of optical scatter using a STAR GEM as a scatterometer [7065-40] E. Kawate, National Institute of Advanced Industrial Science and Technology (Japan) and TRAS Inc. (Japan)

706516 Determining thickness of films on a curved substrate by use of ellipsometric measurement [7065-41]

C.-Y.Han, National United Univ. (Taiwan); Z.-Y. Lee, Y.-F. Chao, National Chiao Tung Univ. (Taiwan) 
706517 Temperature fiber optic sensor using a thermosensible hydrogel [7065-42]

R. Coello, M. Arcos, D. Chana, K. Contreras, G. Baldwin, J. C. Rueda, Pontificia Univ. Católica del Perú (Peru); M. Lomer, Univ. of Cantabria (Spain)

706518 Optical diffraction by inhomogeneous volume objects [7065-43]

G. Forte, A. Lencina, M. Tebaldi, N. Bolognini, Ctr. de Investigaciones Ópticas (Argentina) and Univ. Nacional de La Plata (Argentina)

7065 1A Combining CPP-ACP with fluoride: a synergistic remineralization potential of artificially demineralized enamel or not? [7065-45]

I. I. El-Sayad, Cairo Univ. (Egypt); A. K. Sakr, Misr Univ. of Science and Technology (Egypt); Y. A. Badr, National Laser Institute of Laser Enhanced Sciences, Cairo Univ. (Egypt)

Author Index 


\title{
Conference Committee
}

\author{
Conference Chairs
}

Zu-Han Gu, Surface Optics Corporation (United States)

Leonard M. Hanssen, National Institute of Standards and Technology (United States)

Program Track Chair

Katherine Creath, Optineering (United States) and College of Optical Sciences, The University of Arizona (United States)

Program Committee

Neil Charles Bruce, Universidad Nacional Autonoma de Mexico (Mexico)

Gary Carver, Princeton Lightwave Corporation (United States)

Mei Graham, Lockheed Martin Corporation (United States)

Dan-Hong Huang, Air Force Research Laboratory (United States)

Alexei A. Maradudin, University of California, Irvine (United States)

Eugenio R. Méndez, Centro de Investigación Científica y de Educación Superior de Ensenada (Mexico)

Soe-Mie F. Nee, National Yang-Ming University (Taiwan)

Arne Roos, Uppsala Universitet (Sweden)

Hendrik Rothe, Helmut-Schmidt Universität, Universität der Bundeswehr Hambug (Germany)

Shouhong Tang, KLA-Tencor Corporation (United States)

Michael E. Thomas, The Johns Hopkins University Applied Physics Laboratory (United States)

\section{Session Chairs}

1 Theory and Analysis I

Alexei A. Maradudin, University of California, Irvine (United States)

2 Instruments and Applications I

Hendrik Rothe, Helmut-Schmidt Universität, Universität der Bundeswehr Hambug (Germany)

3 Theory and Analysis II

David A. Cardimona, Air Force Research Laboratory (United States) 
$4 \quad$ Instruments and Applications II

Soe-Mie F. Nee, National Yang-Ming University (Taiwan)

5 Optical Diagnostics I

Leonard $\mathbf{M}$. Hanssen, National Institute of Standards and Technology (United States)

6 Tissue Optics and Drug Analysis

Gary E. Carver, Princeton Lightwave Corporation (United States)

$7 \quad$ Optical Diagnostics II

Michael E. Thomas, The Johns Hopkins University Applied Physics Laboratory (United States)

8 Theory and Analysis III

Zu-Han Gu, Surface Optics Corporation (United States)

9 Optical Diagnostics III

Mei Graham, Lockheed Martin Corporation (United States) 